\title{
Study on the Migration Rules of Sb in Antimony Ore Soil Based on HYDRUS-1D
}

\author{
Yao Zhang1,2, Bozhi Ren ${ }^{1,2 *}$, Andrew S Hursthouse ${ }^{1,3}$, \\ Renjian Deng ${ }^{1,2}$, Baolin Hou ${ }^{1,2}$ \\ ${ }^{1}$ Hunan Provincial Key Laboratory of Shale Gas Resource Exploitation, Xiangtan, China \\ ${ }^{2}$ School of Civil Engineering, Hunan University of Science and Technology, Xiangtan, China \\ ${ }^{3}$ School of Science and Sport, University of the West of Scotland, Paisley, United Kingdom
}

Received: 2 December 2017

Accepted: 12 February 2018

\begin{abstract}
Since waste residues of antimony ores are piled in a disorderly way long-term, heavy metal elements of the residues are dissolved and precipitated under the eluviation effect of snow and rain, causing serious pollution to the surrounding soil. This paper takes the antimony ore of Hunan stannary as the research area, and the surrounding soil of the storage yard of antimony ores as the research object, and carries out research on the migration rules of $\mathrm{Sb}$ in the leachate of waste residues of antimony ores in soil by means of spot sampling, lab analysis, and test and simulation, and simulates the migration of $\mathrm{Sb}$ in the surrounding soil of mining areas. The results show that through the dynamic penetration experiment of indoor soil columns, the hydrodynamic dispersion coefficient $\left(\mathrm{D}=2.485 \mathrm{~cm}^{2} / \mathrm{h}\right.$ ), adsorption distribution coefficient $\left(\mathrm{K}_{\mathrm{d}}=48.826 \mathrm{~cm}^{3} / \mathrm{g}\right)$, retardation factor $\left(\mathrm{R}_{\mathrm{d}}=78.50\right)$, and other parameters of Sb migrating in soil are obtained; the study makes use of the HYDRUS-1D model to conduct dynamic simulation of $\mathrm{Sb}$ in the soil nearby the antimony mine areas on the stannaries of Hunan Province, and the results indicate that the measured value is quite close to the fitted value, and in the correlation analysis of double variables, $\mathrm{R}$ is equal to 0.986 , indicating that the simulation effect is fairly good. This study aims to provide a theoretical foundation and scientific basis for evaluating, controlling, curbing, and repairing the surrounding ecological environment of antimony mine areas.
\end{abstract}

Keywords: HYDRUS-1D, antimony ore, Sb, migration rules

\section{Introduction}

In the surrounding soil of areas of antimony ores mining, mineral separation, and smelting, the content of antimony increases markedly, and the reason is on the one hand, in the mining and separation process of

*e-mail: 800912deng @sina.com

antimony ores, native antimony ore residual particles formed by antimony-bearing rocks and the formation of secondary minerals result in antimony obviously being enriched in the surrounding soil of mining areas [1-2]. On the other hand, the "three waste" materials produced in the mining, separation, and smelting processes of antimony ores become an important source of soil antimony pollution around the mining areas through the wet and dry deposition of atmosphere, rain leaching of waste residues, and waste water irrigation [3-4]. 
HYDRUS-1D and advances on the basis of SUMATRA, WORM, SWMI, and other models, can simulate the migration and reaction of one-dimensional flow, nitrogen-phosphorus element, heat, and carbon dioxide in the saturated and unsaturated media on a micro or macro scale, and besides, users can make a precise subdivision of grid based on the actual situation of the medium structure, and simulate the transport of a variety of water flows and solutes according to different reactants and boundary conditions. Currently, it has been widely used in agriculture, water conservancy, microbiology, environmental science, and other fields [5-7].

\section{Materials and Methods}

\section{Profile of the Research Area}

The antimony ore of Hunan stannary is located in Lengshuijiang, a county-level city in the middle of Hunan Province, and its geographical coordinates are $\mathrm{N} 27^{\circ} 30^{\prime} 49^{\prime \prime} \sim \mathrm{N} 27^{\circ} 50^{\prime} 38^{\prime \prime}, \mathrm{E} 111^{\circ} 18^{\prime} 5^{\prime \prime} \sim \mathrm{E} 111^{\circ} 36^{\prime} 40^{\prime \prime}$. The terrain of the city is high in the north and south and low in central areas, and takes on an asymmetrical saddle shape, and it belongs to subtropical continental monsoon moist climate. Affected by continental coldhigh pressure, northerly winds prevail in winter, and the prevailing wind directions are NE and NNE, and due to subtropical high pressure, southerly winds prevail in summer, and the prevailing wind directions are $\mathrm{S}$ and SSE. Lengshuijiang has four distinctive seasons and is abundant in rainfall, especially at the end of spring and the beginning of summer, with less rain in the height of summer and early autumn. Its average annual rainfall is $1,444.0 \mathrm{~mm}$

\section{Sample Collection and Analysis \\ Sample Collection and Preprocessing of Waste Residues of Antimony Ores}

This study collects the samples (waste stone, smelting slag, milltailings) of waste residues of antimony ores by means of spatial simple random distributed points (as shown in Fig. 1), and each point respectively takes three layers of samples $(0-0.4 \mathrm{~m}, 0.4-0.8 \mathrm{~m}, 0.8-1.2 \mathrm{~m})$ with $0.5 \mathrm{~kg}$ or so for each, after mixing the samples of three layers of each point, put it into a special sample bag, in order to prevent the change of water content in slag sample results in the change of sample properties, eliminate air in the sample bag after bagging and seal and sample bag. Take the three samples of waste residues of antimony ores back to the laboratory and make them dry naturally, respectively mix the three kinds of waste residues evenly on the pulverizer, filter them through nylon mesh (respectively through $8 \mathrm{~mm}$, $0.83 \mathrm{~mm}, 0.38 \mathrm{~mm}$, and $0.15 \mathrm{~mm}$ mesh), and keep them for stand-by application.

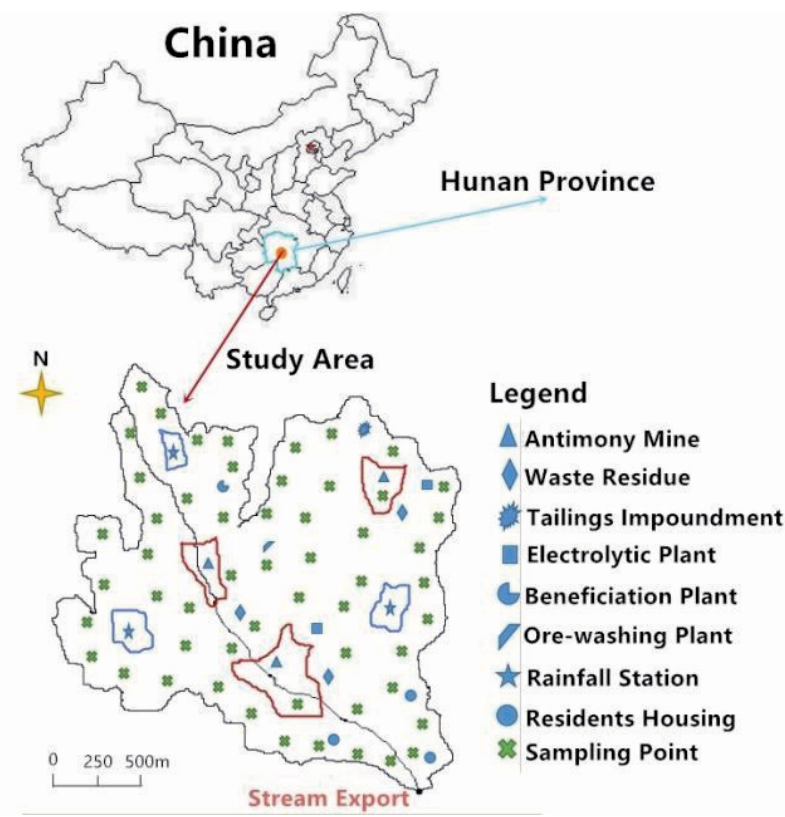

Fig. 1. Profile of research area.

\section{Collecting Soil Samples and Physical and Chemical Analysis}

The soil samples collected in this study are the unpolluted undisturbed soils in the close region of antimony ores of the stannary. When collecting the soil samples, strip off the dead twigs and withered leaves on the surface, adopt a stratified collection, and try not to damage the structure of soil. In addition, collect samples with a soil engineering cutting ring (diameter $6.18 \mathrm{~cm}$ and height $4 \mathrm{~cm}$ ) in the same position, and after sealing the collected samples (including the samples of cutting ring) with polyethylene plastic bags, quickly take them back to the laboratory for processing. The measured results are shown in Table 1.

\section{Experiment and Results}

\section{Semi-Dynamic Leaching Experiment}

Semi-dynamic leaching experiment [8-9]: take $500 \mathrm{~g}$ waste stone, smelting slag, and milltailings of antimony ores, place them in the leaching column and gently vibrate the leaching column so that the waste residues will be dense and thick, then lay a piece of qualitative filter paper on the surface of waste to ensure that the water distribution is uniform when simulating the leaching of acid rain, and add $500 \mathrm{~mL}$ hyperpure water to wet the waste residues in the leaching column and dewater them after 24 hours. Every day add pH 5.0 (annual weighted average of antimony mine areas), representing the simulated acid rain amount from January to December, and conduct a semi-dynamic leaching with a peristaltic pump keeping the velocity at $30 \mathrm{~mL} / \mathrm{h}$. The experiment is a total of 12 cycles (parallel and double samples), and 
Table 1. Analysis of physical and chemical properties of soil.

\begin{tabular}{|c|c|c|c|c|}
\hline Item & \multicolumn{3}{|c|}{ Index content and measured value } \\
\hline $\begin{array}{c}\text { Particle size content } \\
(\%)\end{array}$ & $\begin{array}{c}\text { Sand particle }(2 \sim 0.05 \mathrm{~mm}) \\
33\end{array}$ & $\begin{array}{c}\text { Silt particle }(0.05 \sim 0.002 \mathrm{~mm}) \\
27\end{array}$ & \multicolumn{2}{c|}{$\begin{array}{c}\text { Clay particle } \\
(<0.002 \mathrm{~mm}) \\
40\end{array}$} \\
\hline \multirow{3}{*}{\begin{tabular}{c} 
Physical properties \\
\cline { 2 - 5 }
\end{tabular}} & Soil category & Soil density $\left(\mathrm{g} / \mathrm{cm}^{3}\right)$ & Soil moisture content (\%) & Porosity $(\%)$ \\
\hline \multirow{3}{*}{\begin{tabular}{c} 
Chemical properties \\
\cline { 2 - 5 }
\end{tabular}} & Red soil & 1.344 & 20.25 & 49.28 \\
\cline { 2 - 5 } & Wh & & Organic matter & Sb content \\
\cline { 2 - 5 } & 6.75 & $\mathrm{KCl}$ & $(\mathrm{mg} / \mathrm{kg})$ \\
\hline
\end{tabular}

based on the different kinds of waste residue (waste rock, smelting slag, and milltailings), the precipitation amount of $\mathrm{Sb}$ in each waste residue in each month of the year was simulated.

Fig. 2 shows the same conditions of the experiment: semi-dynamic leaching with the solution with $\mathrm{pH} 5$. The different conditions of the experiment: the different kinds of waste residue (waste rock, smelting slag, and milltailings). The experiment result: the precipitation amount of $\mathrm{Sb}$ in each waste residue. Thereinto 12 days of the experiment respectively represent the 12 months of the year. See Fig. 2 for the variation of $\mathrm{Sb}$ with time under the conditions of simulating a semi-dynamic leaching of different waste residues of antimony ores.

\section{Dynamic Penetration Experiment of Soil Column}

Soil column experiment [10-11]: lay a piece of qualitative filter paper, non-woven fabrics, and $5 \mathrm{~cm}$ thick quartz sand rinsed thoroughly at the bottom before putting it into the soil column, then put the soil with the aggregate thickness of $10 \mathrm{~cm}$ into it in a stratified manner (soil of each layer is $2 \mathrm{~cm}$ thick, and make the soil density close to that of the site with a wooden stick, namely $\rho=1.344 \mathrm{~g} / \mathrm{cm}^{3}$ ). After soil filling is completed, add a layer of $3 \mathrm{~cm}$ clean quartz sand and a piece of

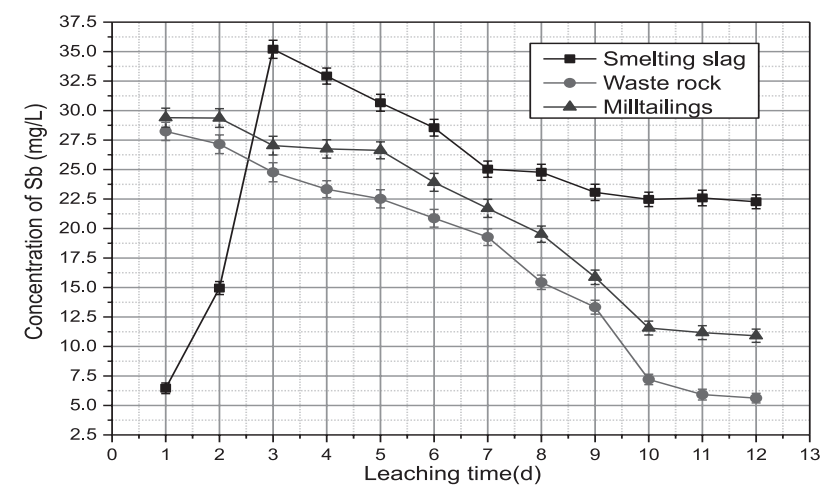

Fig. 2. Leaching and precipitation of antimony in different categories of wastes. qualitative filter paper on the surface of soil in turn to make the water distribution evenly in the test, and control the leaching rate with a peristaltic pump (as shown in Fig. 3).

In the penetration test of $\mathrm{Cl}^{-}$(the solution concentration of standard $\mathrm{Cl}^{-}$is $0.01 \mathrm{~mol} / \mathrm{L}$ ), and the change rule of the concentration of chloride ions with time is shown in Fig. 4.

In the penetration test of $\mathrm{Sb}$ in the tested soil, take the same test devices used in the penetration test of chloride ions (the concentration of standard Sb solution is $10 \mathrm{mg} / \mathrm{L}$ and the $\mathrm{pH}$ of the standard antimony solution is 8.0), and the change rule of the concentration of $\mathrm{Sb}$ at the sample exit at the bottom of the soil column along with time is shown in Fig. 5 (when the antimony concentration reached $9.979 \mathrm{mg} / \mathrm{L}$ after the 1,780-hour experiment, the $\mathrm{pH}$ of leachate at the bottom of the soil column was 7.9).

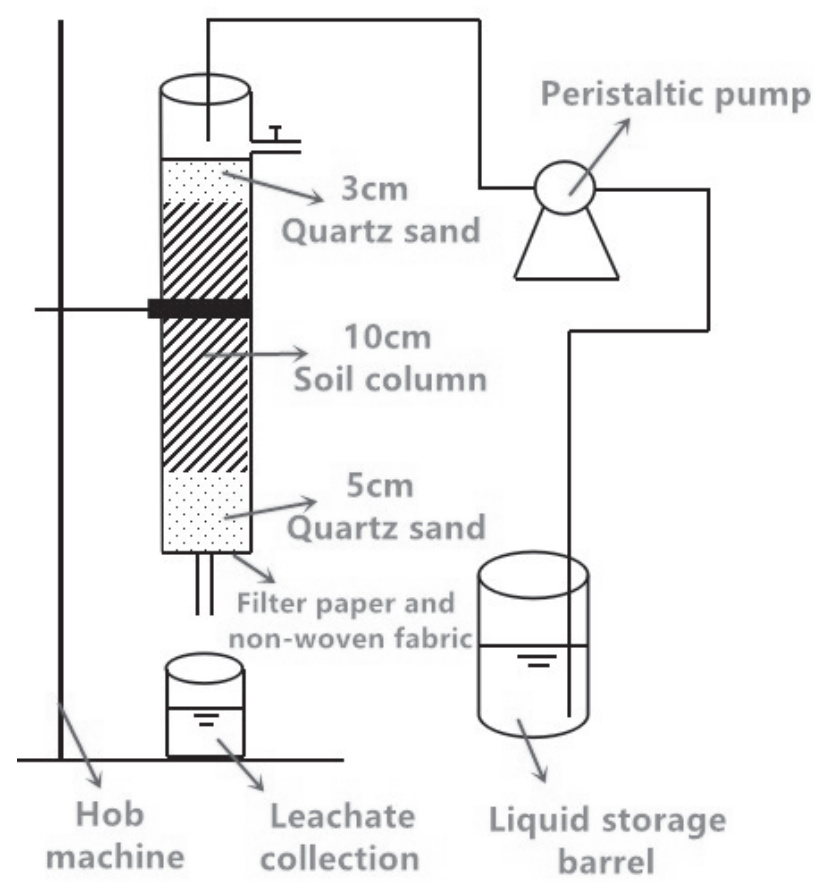

Fig. 3. Device of soil column experiment. 


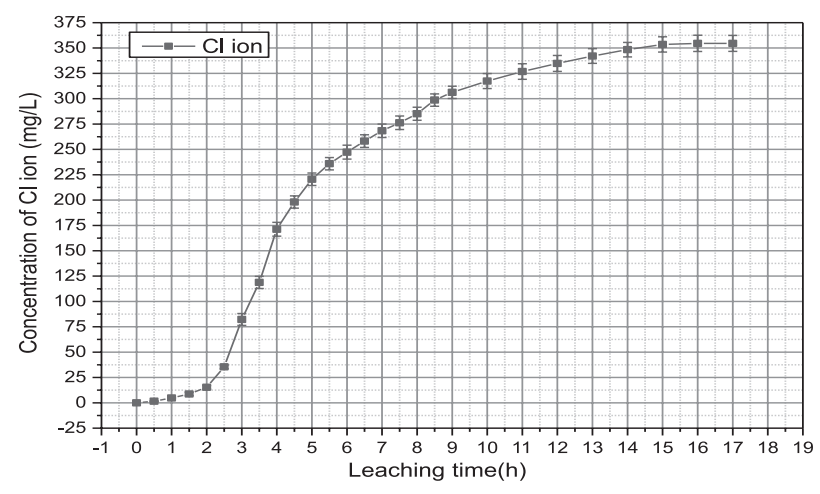

Fig. 4. Breakthrough curve of $\mathrm{Cl}^{-}$in soil.

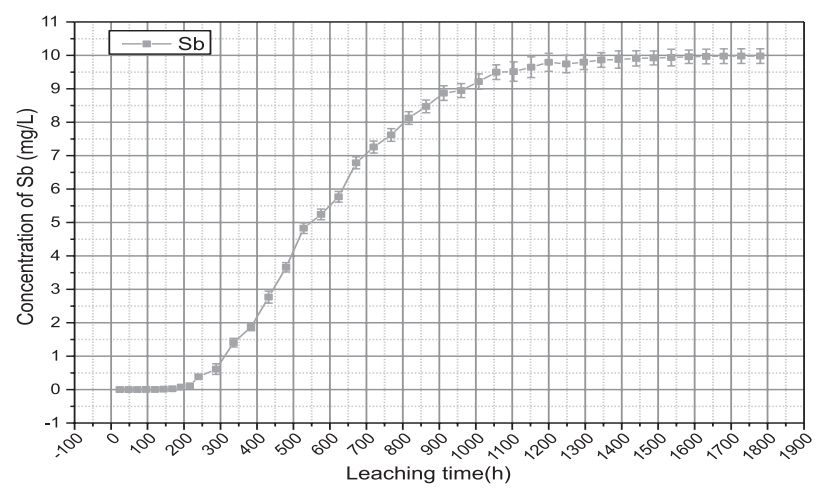

Fig. 5. Breakthrough curve of Sb concentrations.

\section{Model Building and Operation}

\section{Equation of Flow and Solute Transport}

In some saturated porous media, the equation of motion of one-dimensional uniform flow is commonly represented by the corrected form of Richards [12], and in the equation, the effects of thermal gradient and vapour-phase period in the process of liquid phase flow are ignored:

$$
\frac{\partial \theta(h)}{\partial t}=\frac{\partial}{\partial z}\left[K(h) \frac{\partial h}{\partial z}+K(\mathrm{~h})\right]-S(h)
$$

...where $\mathrm{h}$ is the pressure head $(\mathrm{L})$, which is positive when saturated and negative when unsaturated; $\theta$ is volume water content $\left(\mathrm{L}^{3} / \mathrm{L}^{3}\right)$; $\mathrm{z}$ is the vertical coordinate $(\mathrm{L})$, which is possible when it is upwards; $\mathrm{S}$ is the source sink term $\left(\mathrm{T}^{-1}\right)$; $\mathrm{t}$ is time $(\mathrm{T})$; and $\mathrm{K}$ is unsaturated hydraulic conductivity $(\mathrm{L} / \mathrm{T})$. The two hydraulic conductivity parameters $\theta(h)$ and $K(h)$ in the equation are the nonlinear functions of the pressure head H. HYDRUS-1D provides 6 different analytical models of hydraulic characteristics. This study adopts the hydraulic conductivity function of the Van Genuchten model [13-14], and the curve function of hydraulic characteristics of the soil is derived based on a large quantity of previous experimental research, and the expression is as follows:

$$
\begin{aligned}
& \theta(h)=\theta r+\frac{\theta s-\theta r}{\left[1+|\alpha h|^{n}\right]^{m}} \\
& K(h)=K s \cdot S e^{l}\left[1-\left(1-S e^{1 / m}\right)^{m}\right]^{2} \\
& S e=\frac{\theta-\theta r}{\theta s-\theta r}
\end{aligned}
$$

...where $\mathrm{m}=1-1 / \mathrm{n}, \mathrm{n}>1 ; \theta$ is the volume moisture content of the soil; $\theta_{\mathrm{s}}$ is the saturated water content of the soil; $\theta_{\mathrm{r}}$ is the residual water content of the soil; $\mathrm{K}_{\mathrm{s}}$ is the saturated hydraulic conductivity; $\mathrm{S}_{\mathrm{e}}$ is the relative saturation; and $\alpha, \mathrm{n}$, and $\mathrm{l}$ are the empirical parameters of the hydraulic characteristic curve.

The model of solute transport of HUDRUS-1D follows the convection-dispersion equation [15-16]. Considering the effect of soil on solute adsorption, the equation of solute control can be expressed as follows:

$$
\begin{gathered}
\frac{\partial \theta c}{\partial t}+\frac{\partial \rho s}{\partial t}=\frac{\partial}{\partial z}\left(\theta D \cdot \frac{\partial c}{\partial z}\right)-\frac{\partial q c}{\partial z}-\mu_{w} \theta c-\mu_{s} \rho s+ \\
+\gamma_{w} \theta+\gamma_{s} \rho-S C_{s}
\end{gathered}
$$

...where $\mathrm{c}$ is the concentration of solute in the solution; $\mathrm{D}$ is the longitudinal dispersion coefficient; $\mathrm{q}$ is the velocity of Darcy single width; $\mu_{w}$ is the first-order natural attenuation coefficient (liquid phase); $\mu_{\mathrm{s}}$ is the first-order natural attenuation coefficient (solid phase); $\gamma_{w}$ is the zero-order reaction rate constant (liquid phase); $\gamma_{\mathrm{s}}$ is the zero-order order reaction rate constant (solid phase); $\rho$ is the density of the soil; $\mathrm{S}$ is the root adsorption item; and $\mathrm{C}_{\mathrm{s}}$ is the concentration of absorption solute in the root system. In this study, ignoring the absorption item of plants and not considering the attenuation of heavy metals, the equation can be simplified as:

$$
\frac{\partial \theta c}{\partial t}+\frac{\partial \rho s}{\partial t}=\frac{\partial}{\partial z}\left(\theta D \cdot \frac{\partial c}{\partial z}\right)-\frac{\partial q c}{\partial z}
$$

Thereinto,

$$
D=\varepsilon \frac{|q|}{\theta}+D^{o} \tau, \tau=\theta^{7 / 3} / \theta s^{2}
$$

...where $\mathrm{D}_{0}$ is the free diffusion coefficient of the solute in the still water; $\varepsilon$ is the degree of dispersion of the soil; and $\tau$ is the tortuous factor of the soil pores, which is related to the soil structure.

\section{Selection of Initial Conditions and Boundary Conditions}

For independent systems, the equations of flow and solute transport must be solved by specifying 
the following conditions [17], soil surface $(z=1)$, and infiltration surface of soil profile $(\mathrm{z}=1)$ :

$$
\begin{aligned}
& \mathrm{h}(z, t)=h_{0}(z), z=0 \text { or } \quad z=l \\
& -K\left(\frac{\partial h}{\partial z}+\cos \alpha\right)=q_{0}(t), z=0 \text { or } z=l \\
& \frac{\partial \mathrm{h}}{\partial z}=0, z=0
\end{aligned}
$$

...where $\mathrm{h}_{0}$ and $\mathrm{q}_{0}$ are the initial values of the boundary pressure head and the water flux of soil.

$$
\left.c(z, t)\right|_{z=\mathrm{a}}=c_{a}(t),\left.c(z, t)\right|_{z=\mathrm{b}}=c_{b}(t)
$$

... and $c_{a}(t)$ and $c_{b}(t)$ are the given concentrations of the two endpoints, $a$ and $b$, in the research area.

$$
\left.\mathrm{n}\left(D \frac{\partial c}{\partial z}-u_{z} c\right) \cos (n, z)\right|_{z=a}=g(t), t \geq 0
$$

...where $\mathrm{g}(\mathrm{t})$ is the given pollutant convection diffusion flux function on the Cauchy conditions of $r$, take a positive value for the research area of inflow and a negative value for the research area of outflow.

\section{Determining Hydrodynamics and Migration Parameters}

\section{Hydrodynamics Parameters and Dispersion Coefficient of Soil Medium}

According to the analysis and measurement results of the soil bulk density and particles after collecting soil on site and drying it naturally in the lab, it is able to obtain all hydrodynamic parameters by inputting Neural Network Prediction in HYDRUS-1D, and the results are shown in Table 2.

This study makes use of the experimental data of the chloride ion (tracer) penetration curve to calculate the hydrodynamic diffusion coefficient (D). Not considering the migration and degradation of chloride ions in soil migration, and process the hydrodynamic diffusion coefficient according to one-dimensional (vertical) issue [18-19], and the approximate solution is calculated with the following formula:

$$
D=\frac{v^{2}}{8 t_{0.5}}\left(t_{0.84}-t_{0.16}\right)^{2}
$$

...where $t_{0.16}$ is the time when the relative concentra-

Table 2. Motion parameters of soil moisture.

\begin{tabular}{|c|c|c|c|c|c|}
\hline$\theta_{\mathrm{r}}$ & $\theta_{\mathrm{s}}$ & $\mathrm{a}$ & $\mathrm{n}$ & $\mathrm{K}_{\mathrm{s}}$ & 1 \\
\hline 0.0911 & 0.4683 & 0.0155 & 1.3691 & 15.96 & 0.5 \\
\hline
\end{tabular}

Table 3. Calculating hydrodynamic dispersion coefficient D.

\begin{tabular}{|c|c|c|c|c|}
\hline$v(\mathrm{~cm} / \mathrm{h})$ & $\mathrm{t}_{0.16}(\mathrm{~h})$ & $\mathrm{t}_{0.5}(\mathrm{~h})$ & $\mathrm{t}_{0.84}(\mathrm{~h})$ & $\mathrm{D}\left(\mathrm{cm}^{2} / \mathrm{h}\right)$ \\
\hline 2.448 & 2.728 & 4.085 & 8.488 & 2.485 \\
\hline
\end{tabular}

tion $\mathrm{C}_{\mathrm{t}} / \mathrm{C}_{0}$ of the sampling point is up to $0.16 ; \mathrm{t}_{0.5}$ and $\mathrm{t}_{0.84}$ is in a similar way; $v$ is the actual flow velocity of flow in soil column, which is determined by $v=\mathrm{L} / \mathrm{t}_{0.5}$; and $\mathrm{L}$ is the actual length of soil column. In this study, $\mathrm{L}$ value is $10 \mathrm{~cm}$. The values of $\mathrm{t}_{0.16}, \mathrm{t}_{0.5}$, and $\mathrm{t}_{0.84}$ are calculated by way of interpolation, and the calculated value of $\mathrm{D}$ is shown in Table 3 .

\section{Sb Absorption Distribution Coefficient and Retardation Factor}

Adsorption can affect the migration of heavy metals in soil and the environmental remediation of the site polluted by heavy metals. At present, it is difficult to solve the adsorbed distribution coefficient $\left(\mathrm{K}_{\mathrm{d}}\right)$ and retardation factor $\left(R_{d}\right)$ with a nonlinear equation. Therefore, the linear adsorption equation is adopted to solve $\mathrm{K}_{\mathrm{d}}$ and $\mathrm{R}_{\mathrm{d}}$ [20-21], and the formula is as follows:

$$
\begin{gathered}
K_{d}=\frac{\eta_{e}}{\rho_{b}}\left(\frac{v t_{0.5}}{L}-1\right) \\
R_{d}=1+\frac{\rho_{b}}{\eta_{e}} \cdot K_{d}
\end{gathered}
$$

...where $\rho_{\mathrm{b}}$ is the dry bulk density of the soil, $\mathrm{g} / \mathrm{cm}^{3} ; \eta_{\mathrm{e}}$ is the effective porosity of the soil medium, $\% ; \mathrm{t}_{0.5}$ is the time when the relative concentration $\mathrm{C} / \mathrm{C}_{0}$ at the sampling point reaches 0.5 (it can be obtained from the penetration curve of Sb in the figure $\mathrm{t}_{0.5}=228.33 \mathrm{~h}$ ), $\mathrm{h}$; $\mathrm{v}$ is the actual flow rate of the solution in the soil column, which can be determined by the formula $\mathrm{v}=\mathrm{L} / \mathrm{t}_{0.5}$; and $\mathrm{L}$ is the distance from the bottom sampling port to the starting point of the soil column (when $\mathrm{L}$ is $10 \mathrm{~cm}$ ).

Put $\rho_{\mathrm{b}}, \eta_{\mathrm{e}}, \mathrm{t}_{0.5}, \mathrm{~L}$, and $\mathrm{v}$ into (8), then: $\mathrm{K}_{\mathrm{d}}=48.826 \times 10^{-3}$ $\left(\mathrm{m}^{3} / \mathrm{kg}\right)$;

Put $\rho_{b}, \eta_{e}$, and $K_{d}$ into (9), then: $R_{d}=78.50$.

\section{Simulation Results and Analysis}

\section{Migration Simulation of Antimony}

The parameters required for simulating the migration of $\mathrm{Sb}$ in the soil column by making use of HYDRUS1D model are shown in Table 4, and when defining the model boundary, define it as the boundary of constant water head ( $5 \mathrm{~cm}$ water head), and set the lower boundary to be the free drainage boundary. The simulation results are shown in Figs 6-7.

In Fig. 6 it can be drawn that the concentration of $\mathrm{Sb}$ at the $10 \mathrm{~cm}$ point of the soil column reaches 
Table 4. Parameters required for migration simulation of Sb.

\begin{tabular}{|c|c|c|c|}
\hline Parameter & Value & Parameter & Value \\
\hline$\theta_{\mathrm{r}}\left(\mathrm{cm}^{3} / \mathrm{cm}^{3}\right)$ & 0.0911 & $\mathrm{~L}(\mathrm{~cm})$ & 10 \\
\hline$\theta_{\mathrm{s}}\left(\mathrm{cm}^{3} / \mathrm{cm}^{3}\right)$ & 0.4683 & $\mathrm{C}_{0}(\mathrm{mg} / \mathrm{L})$ & 10 \\
\hline $\mathrm{a}(1 / \mathrm{cm})$ & 0.0155 & $\rho_{\mathrm{b}}\left(\mathrm{g} / \mathrm{cm}^{3}\right)$ & 1.344 \\
\hline $\mathrm{n}$ & 1.3691 & $\mathrm{~K}_{\mathrm{d}}\left(\mathrm{cm}^{3} / \mathrm{g}\right)$ & 48.826 \\
\hline $\mathrm{K}_{\mathrm{s}}(\mathrm{cm} / \mathrm{h})$ & 0.665 & $\mathrm{D}\left(\mathrm{cm}^{2} / \mathrm{h}\right)$ & 2.485 \\
\hline 1 & 0.5 & $\mathrm{~T}(\mathrm{~h})$ & 2400 \\
\hline
\end{tabular}

$9.1 \mathrm{mg} / \mathrm{L}$ after 1000-hour migration; in Fig. 7 it can be drawn that the measured values (Fig. 5) and the simulated value are very close to each other, and the bivariate correlation analysis is conducted via SPSS19.0: the correlation coefficient between the measured value and the simulated value is $0.986(\mathrm{P}=0.001)$, which indicates that the model can well simulate the migration of $\mathrm{Sb}$ in the local soil and the simulation results are relatively reliable.

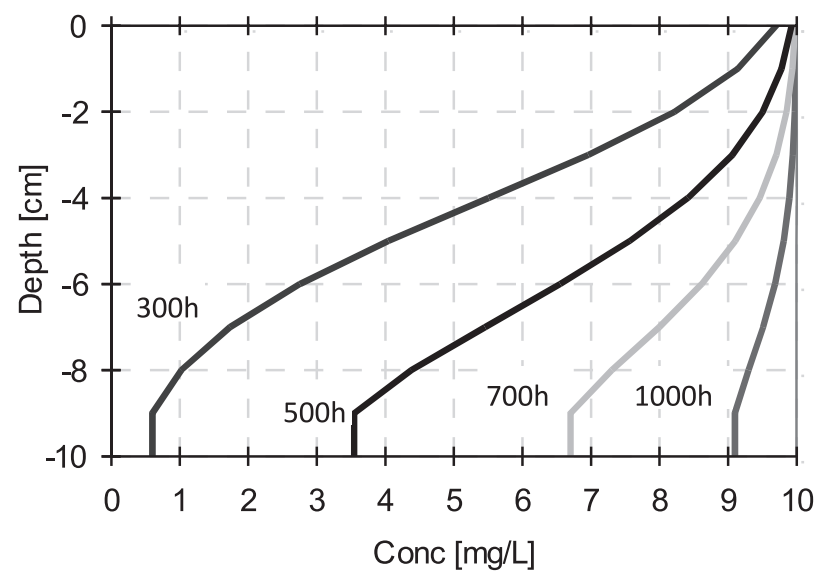

Fig. 6. Distribution of $\mathrm{Sb}$ content of soil profile at different times.

\section{Observation Nodes: Concentration}

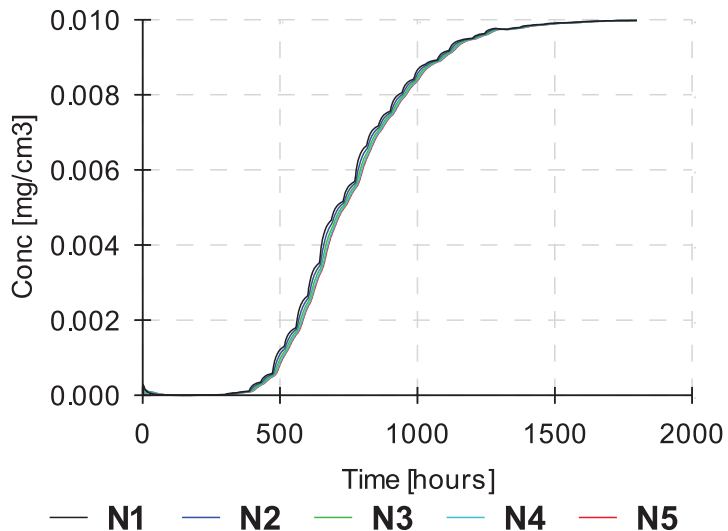

Fig. 7. Predicted value of simulation of Sb content at observation points.

\section{Application and Prediction of Antimony Migration Model}

According to the release rule of $\mathrm{Sb}$ under the conditions of simulating acid rain leaching of waste residues of antimony ores, we can conclude that the concentration of $\mathrm{Sb}$ in acid rain leaching of smelting slags of antimony ores is the highest at $35.20 \mathrm{mg} / \mathrm{L}$. This study takes the highest concentration of $\mathrm{Sb}$ in leaching solution as the concentration of input liquid, builds the model with HYDRUS-1D, and makes use of the parameters of Table 4 to simulate the migration of $\mathrm{Sb}$ in the storage yard of waste residues of antimony ores in the surrounding soil. According to the actual investigation on groundwater levels in the surrounding soil in the storage yard of waste residues of antimony ores, it is found that the groundwater level is shallow, and is generally $70-90 \mathrm{~cm}$ from the surface. Assuming that the soil is $80 \mathrm{~cm}$ thick, simulate the migration of $\mathrm{Sb}$ into the soil and analyze possible groundwater pollution. See Fig. 8 for simulation results.

Fig. 8 shows that it takes more than 500 days for the $\mathrm{Sb}$ in storage yard of waste residues of antimony ores to penetrate $80 \mathrm{~cm}$-thick soil, indicating that the penetration ability of $\mathrm{Sb}$ is relatively weak. It requires $597.3 \mathrm{~d}$ to completely penetrate the $80 \mathrm{~cm}$ soil, but only needs $160.3 \mathrm{~d}$ to produce the leachate exceeding the limit value

a)
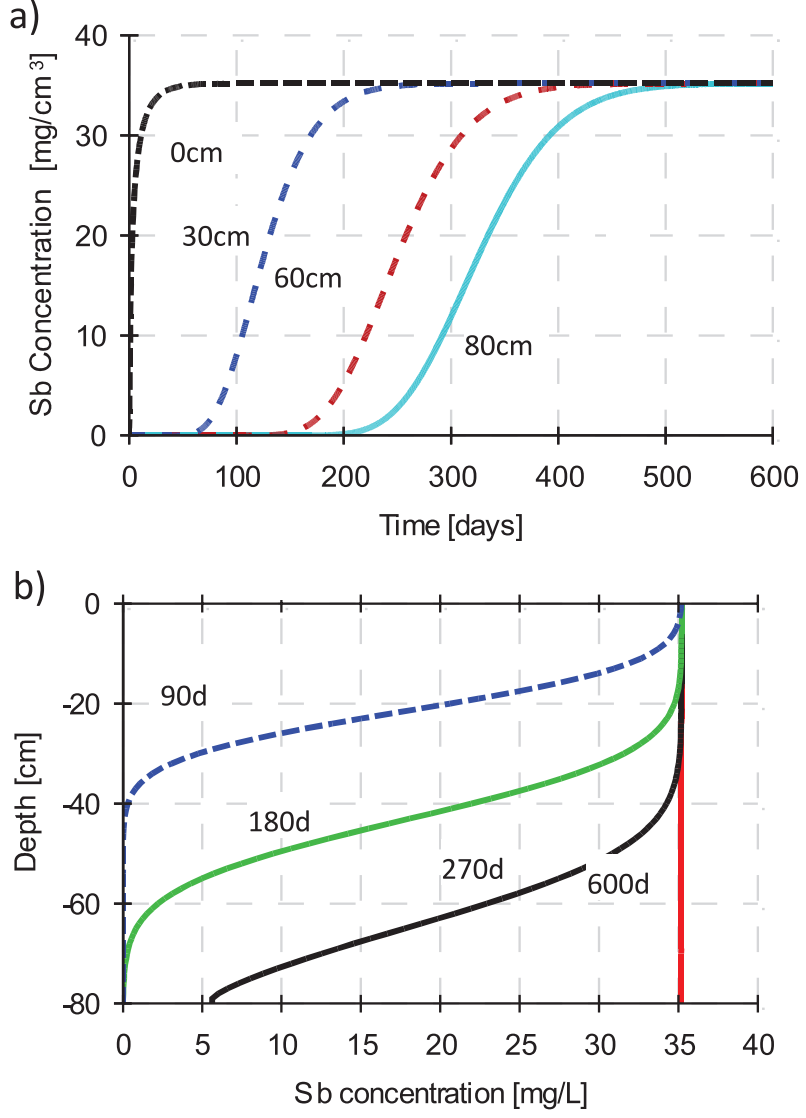

Fig. 8. Predicting results of the migration of $\mathrm{Sb}$ in soil for 600 days; a) different profile depths and b) different times/d. 
$(0.005 \mathrm{mg} / \mathrm{L})$ of the sanitary standard for drinking water, which is injected into the groundwater. With the increase in the deposit volume of waste residues of antimony ores, the concentration of $\mathrm{Sb}$ in the leaching solution of waste residues of antimony ores is also enhanced.

\section{Conclusions}

This study carried out an analytical test of hydrodynamic and migration parameters of $\mathrm{Sb}$ in soil by means of an indoor soil column test. In addition, it takes a mathematical model to simulate the migration of $\mathrm{Sb}$ in the soil column, and on the basis of the $\mathrm{Sb}$ migration model and $\mathrm{Sb}$ precipitation rule under the conditions of simulating the acid rain leaching of waste residues of antimony ores, it conducted a simulation and prediction of the migration of $\mathrm{Sb}$ in the leaching solution of waste residues of antimony ores in the waste residue disposal site of mine areas as well as its pollution to the groundwater, and the conclusions are as follows:

1) The study takes advantage of the indoor soil column dynamic simulation test to obtain the hydrodynamic dispersion coefficient ( $\mathrm{D}=2.485 \mathrm{~cm}^{2} / \mathrm{h}$ ), adsorption distribution coefficient $\left(\mathrm{K}_{\mathrm{d}}=48.826 \mathrm{~cm}^{3} / \mathrm{g}\right)$, and retardation factor $\left(R_{d}=78.50\right)$, and like $S b$ in soil migration, the time required for $\mathrm{Sb}$ to completely penetrate the soil column is 100 times that of $\mathrm{Cl}^{-}$, indicating that $\mathrm{Sb}$ has obvious tailing phenomena in soil migration.

2) It takes advantage of the HYDRUS-1D model to conduct a dynamic simulation of the migration of $\mathrm{Sb}$ in the surrounding soil of antimony mine areas of Hunan stannary, and the results show that the measured value and the predicted value are rather close to each other, and the analyzed bivariate correlation is $\mathrm{R}=0.986$, indicating that the simulation parameters were selected appropriately.

3) The study applies the HYDRUS-1D model in the migration simulation of $\mathrm{Sb}$ in the surrounding soil of the storage yard of waste residues of antimony ores, and it takes $597.3 \mathrm{~d}$ for $\mathrm{Sb}\left(\mathrm{C}_{0}=35.2 \mathrm{mg} / \mathrm{L}\right)$ in the leaching solution of waste residues of antimony ores to completely penetrate the $80 \mathrm{~cm}$ soil in the surrounding storage yard of waste residues. Therefore, the leaching solution of waste residues in the storage yard of waste residues of antimony ores cause serious $\mathrm{Sb}$ pollution to the surrounding environment.

\section{Acknowledgements}

This work was supported by the National Natural Science Foundation of China (No. 41472328) and Hunan Postgraduate Research Innovation Program (No. CX2016B559).

\section{Conflict of Interest}

The authors declare no conflict of interest.

\section{References}

1. BECH J., CORRALES I., TUME P., BARCELÓ J., DURAN P., ROCA N., POSCHENRIEDER C. Accumulation of antimony and other potentially toxic elements in plants around a former antimony mine located in the Ribes Valley (Eastern Pyrenees). J. Geochem. Explor. 113, 100, 2012.

2. GAUSZKA A., MIGASZEWSKI Z.A.M., DOGOWSKA S., MICHALIK A., DUCZMAL-CZERNIKIEWICZ A. Geochemical background of potentially toxic trace elements in soils of the historic copper mining area: a case study from Miedzianka Mt., Holy Cross Mountains, southcentral Poland. Environ. Earth Sci. 74, 4589, 2015.

3. HILLER E., LALINSKÁ B., CHOVAN M., JURKOVIC L., KLIMKO T., JANKULÁR M., HOVORIČ R., ŠOTTNÍK P., FLAKOVA R., ENIŠOVÁ Z.Ž., ONDREJKOVÁ I. Arsenic and antimony contamination of waters, stream sediments and soils in the vicinity of abandoned antimony mines in the Western Carpathians, Slovakia. Appl. Geochem. 27, 598, 2012.

4. RITCHIE V.J., ILGEN A.G., MUELLER S.H., TRAINOR T.P., GOLDFARB R.J. Mobility and chemical fate of antimony and arsenic in historic mining environments of the Kantishna Hills district, Denali National Park and Preserve, Alaska. Chem. Geol. 335, 172, 2013.

5. WIKINIYADHANEE R., CHOTPANTARAT S., ONG S.K. Effects of kaolinite colloids on $\mathrm{Cd}(2)(+)$ transport through saturated sand under varying ionic strength conditions: Column experiments and modeling approaches. J. Contam. Hydrol. 182, 146, 2015.

6. MASIPAN T., CHOTPANTARAT S., BOONKAEWWAN S. Experimental and modelling investigations of tracer transport in variably saturated agricultural soil of Thailand: Column study. Sustainable Environment Research. 26, 97, 2016.

7. NGUYEN M.N., DULTZ S., PICARDAL F., BUI A.T., PHAM Q.V., DAM T.T., NGUYEN C.X., NGUYEN N.T., BUI H.T. Simulation of silicon leaching from flooded rice paddy soils in the Red River Delta, Vietnam. Chemosphere. 145, 450, 2015.

8. CETIN B., AYDILEK A.H., LI L. Leaching Behavior of Aluminum, Arsenic, and Chromium from Highway Structural Fills Amended with High-Carbon Fly Ash. Transportation Research Record Journal of the Transportation Research Board. 2349, 72, 2013.

9. TIWARI M.K., BAJPAI S., DEWANGAN U.K., TAMRAKAR R.K. Suitability of leaching test methods for fly ash and slag: A review. Journal of Radiation Research \& Applied Sciences. 8, 523, 2015.

10. NAKA A., YASUTAKA T., SAKANAKURA H., KALBE U., WATANABE Y., INOBA S., TAKEO M., INUI T., KATSUMI T., FUJIKAWA T. Column percolation test for contaminated soils: Key factors for standardization. J. Hazard. Mater. 320, 326, 2016.

11. YASUTAKA T., NAKA A., SAKANAKURA H., KUROSAWA A., INUI T., TAKEO M., INOBA S., WATANABE Y., FUJIKAWA T., MIURA T. 
Reproducibility of up-flow column percolation tests for contaminated soils. Plos One. 12, e178979, 2017.

12. LIPNIKOV K., MOULTON D., SVYATSKIY D. New preconditioning strategy for Jacobian-free solvers for variably saturated flows with Richards' equation. Adv. Water Resour. 94, 11, 2016.

13. GUARRACINO L. Estimation of saturated hydraulic conductivity Ks from the van Genuchten shape parameter $\alpha$. Water Resour. Res. 431, 2007.

14. BERGAMASCHI L., PUTTI M. Mixed finite elements and Newton - type linearizations for the solution of Richards' equation. Int. J. Numer. Meth. Eng. 45, 1025, 2015.

15. SANTOS G.G.E., SILVA E.M.D., O R.L.L.M., SILVEIRA P.M.D., BRUAND A., JAMES F., BECQUER T. Analysis of physical quality of soil using the water retention curve: Validity of the S -index. Cr Geosci. 343, 295, 2011.

16. MIKAILSOY F., PACHEPSKY Y. Average concentration of soluble salts in leached soils inferred from the convective - dispersive equation. Irrigation Sci. 28, 431, 2010.

17. STEENPASS C., VANDERBORGHT J., HERBST M., SIMUNEK J., VEREECKEN H.: Using IR-measured soil surface temperatures to estimate hydraulic properties of the top soil layer, Proceedings, EGU General Assembly Conference, 2010.

18. AGAH A.E., WYSEURE G. Experimental investigation of water flow and solute transport in unsaturated columns. International Journal of Agriscience. 03, 543, 2013.

19. CHOU P.Y., WYSEURE G. Hydrodynamic dispersion characteristics of lateral inflow into a river tested by a laboratory model. Hydrology \& Earth System Sciences. 13, $217,2009$.

20. LOZOWICKA B., JANKOWSKA M., RUTKOWSKA E., KACZYNSKI P., HRYNKO I. Comparison of Extraction Techniques by Matrix Solid Phase Dispersion and LiquidLiquid for Screening 150 Pesticides from Soil, and Determination by Gas Chromatography. Pol. J. Environ. Stud. 21, 973, 2012.

21. BENTUM J.K., DODOO D.K., KWAKYE P.K., ESSUMANG D.K., ADJEI G.A. Spatial and Temporal Distribution of Polychlorinated Biphenyl Residues in Tropical Soils. Open Journal of Applied Sciences. 06, 234, 2016. 